\title{
Mega-events and the Preservation of Urban Heritage: Literature Gaps, Potential Overlaps, and a Call for Further Research
}

\author{
Zachary M. Jones' and Davide Ponzini'
}

\begin{abstract}
Despite mega-events being long perceived as great opportunities by urban policy makers, several cities have recently withdrawn bids for the Olympic games. The disconnect between the planning of mega-events and the urban environment is a reoccurring argument in public debate, but missing in research. In this article, we consider how the relationship between mega-events and urban heritage has been discussed in literature, examining the gaps and potential overlaps, why they exist, and further argue the need to bridge disciplines. In conclusion, we outline new perspectives for studying and learning from the crossroad of the two policy fields, namely, cultural mega-events.
\end{abstract}

\section{Keywords}

mega-events, urban heritage, historic preservation, governance, policy making

\section{Emerging Problems and the Gap between the Literatures of Mega-events and Urban Heritage}

The Eiffel Tower in Paris, the Atomium in Brussels, and the Bird's Nest in Beijing have all become powerful icons and modern symbols of their cities. They, among many others, are also the visible results of mega-events. The Olympics, Expo, or the World Cup have long been highly desirable events for cities to host, not only to generate new icons or increase visibility but also to provide momentum to urban transformations. In the last decades, they have come to be characterized by large investment schemes and opportunities to build massive structures, stadiums, and infrastructure. However, today cities have begun to question this paradigm. For both the 2022 Winter Olympic and 2024 Summer Olympic bids, four out of six candidate cities withdrew from the competition. The long-utilized equation of the mega-event as an opportunity for mega-expenditures and mega-constructions no longer adds up for many cities. The processes for refusing these events have occurred both through popular referendum, as in Boston and Hamburg, and through top-down political decisions, like in Rome, where a newly elected mayor decided the city was in neither the appropriate financial nor urban conditions to host the Olympics.

In response, the International Olympic Committee (IOC) has developed Agenda 2020, a document that sets a new vision for the future of Olympic events. Specifically, recommendation 2.2 aims to alter the most visible and once celebrated aspect of the event, instead promoting: "The maximum use of existing facilities and the use of temporary and demountable venues where no long-term venue legacy need exists or can be justified" (IOC 2014). This shift could result in Olympics becoming either more integrated into existing city fabric as well as diffused through a network of regional connections. We can already observe this shift occurring in Paris hosting the 2024 Olympics. The city intends to place key events and venues within the historic city. Here, sites like the Eiffel Tower will form the backdrop for the upcoming games (Mairs 2017). The planning of this event will deal with very different sites from the typical isolated platform, which can be more easily ticketed and secured (Boyle and Haggerty 2009).

As sporting mega-event proponents begin to envision this new paradigm of operation, historic- and heritage-rich cities can provide beneficial examples of how to properly integrate large events within existing city fabric. When cities construct event venues on the outskirts, with a stratified, yet clear structure, their impact on the rest of the urban fabric may be negligible. However, this shift toward using the city itself along with existing structures or temporary venues for the event can increase the direct (positive or negative) impact. The range of impacts span from potential physical alterations to the city to less tangible reinterpretations of the image of the city (eventually represented by the abovementioned icons). The decisions made for mega-events can potentially significantly (and

\footnotetext{
' Dastu, Politecnico di Milano, Milano, Italy

Corresponding Author:

Zachary M. Jones, Politecnico di Milano, Via Edoardo Bonardi, 3, Milano 20133, Italy.

Email: zachary.jones@polimi.it
} 
perhaps irreversibly) alter the physical and social qualities of a historic city area and its heritage value.

For example, an event can rapidly introduce mass tourism into a sensitive context, potentially greatly impacting both the physical and the social qualities of these places. The historic nature of cities like Rome or Budapest (both involved in the 2024 Olympics bid) and their preservation policy can also inversely impact the planning of the event itself through existing conservation restrictions on what changes can be made and where.

The decisions for these events are often granted special powers and funds, bypassing more ordinary regulation and decision-making procedures. However, the large budgets afforded to mega-events could become a much needed source of funding for the preservation of heritage in a sort of give-andtake (e.g., new functions for unused structures and revitalization of underexploited parts of cities). While physical changes may be the most immediately visible, events could also change the management and governance networks of heritage areas, as well as the understandings and uses of them, which might have the most lasting impact. In this sense, urban heritage, due to its potential vulnerabilities and restrictions, becomes an ideal testing ground to observe the process of planning mega-events in valuable city fabric and to make the frictions between fast-track development and urban preservation evident.

In this article, we will provide the definitions and background of mega-events and urban heritage and see how these policies have been presented in literature. Perhaps, with a higher relevance derived from an emerging shift toward a more integrated mega-event planning strategy, one can see the gap that exists within planning literature that directly considers and analyzes mega-events within historic realms, more specifically in the relationship between mega-event planning and preservation policy. This article will therefore examine this gap, consider its features, and further argue the need to bridge this gap both in theory and in practice, calling for further reflection and research.

\section{Why Is Building This Common Ground Important in Practice and in Theory? Who Is It For?}

The goal of this literature review is to increase knowledge for both planning research and practice. Perhaps most obvious, to avoid the risk of damaging the historic city environment or its image for the sake of planning and managing a mega-event and the (often decontextualized) urban redesign and growth assumed to come attached to any mega-event. Secondly, a key issue is interpreting heritage preservation and urban planning measures for historic/landscape matters in ways that, pragmatically, do not prevent from relating the existing city to the planning and development of mega-events. The third consideration relates to the fact that decisions made for mega-events typically exist from solely a short-term perspective. Though legacy is a highly discussed aspect, it is a much vaguer concept during the planning phase compared to the strict deadlines of the impending event. Yet heritage concerns must be taken into a long-term perspective, which could eventually be built into the short-term delivery model.

In our view, specific aspects of the frictions and gaps between the fields of heritage preservation and mega-event planning need further deepening and discussion. First, each field may learn and integrate its approaches to the city by drawing on the other. Second, being aware that mega-event planning and heritage preservation can coexist and work together presents a new paradigm for cities and conservation practitioners and expand existing ones in new directions. Thirdly, the shifting paradigm for mega-events like the Olympics becoming more embedded within the existing city suggests a new emerging relationship between events and cities that necessitates changes to their planning, governance, and physical implementation. Therefore, addressing the gaps and overlaps of these two fields in theory and practice seems a necessary exercise.

This article faces the more general question: how and to what extent does the literature cover the issues facing cultural heritage areas that become the site of mega-events? In order to answer this question, the following section will explore these two divergent literatures and conclude by highlighting the points of connection and how research and practice can utilize them. This article identifies and discusses given topics within the two streams of literature as follows: definition and history of the policy phenomenon and governance as well as its economic, infrastructural, touristic, and sociocultural dimensions. This review is therefore aimed at policy makers and researchers in both fields to introduce this link by showing that a gap does exist, but so do many overlaps. In our opinion, both fields would benefit from researching with and planning for the other.

\section{Literature Review of Mega-events and Heritage Preservation}

This review will progress through the definition of megaevents provided in the literature and review the planning, policy, and governance; economic; touristic and sociocultural dimensions, followed by a separate overview of the same definition and dimensions in heritage preservation literature. The article focuses on these two separate strands of urban debate to show how they run parallel but will highlight throughout the many possible contact points and the high potential of crossfertilization.

\section{Definition and History of Phenomenon of Mega-events and Their Governance}

For the last 150 years, mega-events have been used as instruments to promote and distinguish cities-since the first World's Fair in London in 1851 or the first modern Olympics staged in 1896 in Athens. During this period, mega-events have taken different shapes and forms, evolving over time and with differing focal points. They inspire a certain preconception pertaining to scale, duration, expense, and transnationality. Mega-events range in time length from two weeks, in the case 
of the Olympics, to six months for the Expo, or more, and are now commonly expected to cost several billions of dollars (Horne 2007). Differentiations have been made between mega-events, special events, and hallmark events (Hall 1989) based on their appeal, audience size, and governing bodies, differentiating, say, the Olympics from a music festival. However, much shorter in duration and requiring far less infrastructural investment and planning, some music festivals attract upward of three million visitors (Claes 2013). When compared to the estimated four million visitors for the 2012 London Olympics (IOC 2013), the contrast and consequences are quite striking and challenge long-held conceptions of a mega-event.

A broadly accepted definition of a mega-event is that of Roche (2000, 1): “.... large-scale cultural (including commercial and sporting) events which have a dramatic character, mass popular appeal and international significance." This broad definition does not necessarily exclude events that are not transnational or governed through specific mechanisms but rather focuses on the general significance and perceived magnitude of the event. Taking this definition, a number of different events could be considered a mega-event. Within the literature, particular qualities of mega-events tend to emerge that the article discusses further in depth. The definition provided by Getz (Fayos-Solin1998, 242) suggests some of these particular qualities as the defining features of a mega-event: ".... planned occurrences of limited duration which have an extraordinary impact on the host area in terms of one or more of the following: tourist volumes; visitor expenditures; publicity leading to a heightened awareness and a more positive image; related infrastructural and organizational developments which substantially increase the destination's capacity and attractiveness."

Intriguingly, the importance of the actual content of the event itself has come to be nearly replaced by the broader desired/perceived outputs and effects of the event. According to its promoters, a mega-event unequivocally translates to an increase in quality of place through the specialized mechanism of the event accompanied by an investment in the physical realm and improvement in the image of the city (Sykes and Brown 2015). This definition represents much of the aura that has long surrounded the discussion of mega-events and attracted cities to pursue hosting them (Essex and Chalkley 2004; Goldman 2011; Müller and Pickles 2015; Roy and Ong 2011). It is these "defining attributes" that have also come to determine a large swath of the literature and make up several of the following sections. Despite attempts to generally define mega-events through inclusive terms, works aimed at discussing the phenomenon as a whole typically tell the story of a specific event, with most narratives describing the Olympics and the Expo, by far the two most well-known and visible mega-events (Andranovich, Burbank, and Heying 2001; Basso 2017; Gold and Gold 2008; Greenhalgh 2011; Hiller 2000; Horne and Whannel 2016; McGillivray and McPherson 2012; Morandi and Di Vita 2017; Roche 2000). Beyond these two specific events exist a number of other transnational sporting events (e.g., Fédération Internationale de Football Association
[FIFA] World Cup, The Union of European Football Associations Champions League) as well as an increasing number of cultural events - most notably the European Capital of Culture $(\mathrm{ECoC})$, a flagship program of the European Commission for over thirty years.

Within this diversity of focus and content of a mega-event, cities tend to manage and utilize them in similar ways as they are viewed as an exception to the typical rules of planning (Morandi and Di Vita 2017). For some events, special laws and governing bodies or outside consultants are established specifically to ensure their expedient delivery (Lauermann 2014; Müller 2014). Events can also be used to complete preexisting projects that have languished through traditional planning processes for years. They are deemed exceptional in that they allow cities to quickly develop infrastructural or megaprojects that otherwise would be impossible to accomplish in such a short time frame. Basso (2017) has found that cities manage and deliver mega-events in similar ways to megaprojects. While specialized planning tools were used in the case of the Milan Expo 2015, the overall organizing structure resembled the same approach that would be implemented in the response to a natural disaster (Basso 2017).

Therefore, both in terms of their content and management, there remains potential for connection and conflict. Cultural mega-events present a clear opportunity to include built heritage as part of actual focus of the program itself and the previous example of Paris 2024 shows this possibility also for sporting events. Yet, as we will discuss in later sections, the management of heritage can be quite restrictive and narrowly controlled, requiring collaboration between mega-event and preservation actors.

\section{Economic Impact of Mega-events}

The largest section of mega-event literature addresses the economics risks and advantages of hosting cities. One of the longstanding arguments in support of hosting events has been the anticipated economic benefits to the city (Getzner and Oberlercher 2003; Herrero et al. 2006; Hiller 2000; Mules and Faulkner 1996; Plaza 2006; Shoval 2002). Nearly every bidding city commissions an economic impact assessment of the event potential beforehand with hopeful host cities producing final reports announcing the positive impact of the event. Academics have weighed in on the discussion, arguing both for and against mega-events based on economic arguments. Over time, various economic models have been debated. In the early 1990s, much of the discussion focused on events as a potential stimulus to local economies, serving as a force of regeneration (Foley, McGillivray, and McPherson 2012; Hughes 1993; Mules 1993; Roche 1992). However, rarely has there been a complete return on investment through ticket sales or private sponsorship, with the 1984 Los Angeles Olympics being one of the few exceptions (notably the bid did not see any competition, so the proposal did not have to overpromise!). Traditionally, cities rely on the calculation of secondary effects in order to claim a net positive economic result of hosting the event. Yet an 
accurate assessment of large events is a highly debated and contentious field (Dwyer, Forsyth, and Spurr 2005).

Various models have been used to conduct economic impact studies. The input-output analysis was long promoted as the primary model to use (Lynch and Jensen 1984). However, more recent studies have pointed out the inability of that method to accurately account for all variables with other scholars turning to cost-benefit analysis or computable general equilibrium models to acquire more accurate outcomes (Burgan and Mules 2000; Dwyer, Forsyth, and Spurr 2005; Faulkner 1993). Multipliers have been introduced to account for the broad range of impacts beyond just the tourism industry to account for indirect and induced cost benefits (Archer 1982; Faulkner 2003). Again, many studies are conducted in preparation of bidding for the event in order to gain public support or demonstrate the benefits a region might receive after hosting an event. While depending on the specific context, these events often receive abundant public funding, from either local or central levels, and the economic impact of these events in evaluating their worth is therefore of particular concern to both politicians and local citizens (Carlsen, Soutar, and Getz 2000).

Yet the calculation of economic impact is far from a perfect science. As Dwyer, Forsyth, and Spurr (2005) point out, a study of economic impact should be of the national economic situation and not just local or city scale as other cities and regions in the state may suffer because of the event. Faulkner (1993, 2003) recognizes economic impact as just one of the areas to study and calls for evaluations to consider the broader range of impacts of events including social, physical, and environmental aspects. This call to broader research echoes Dunstan and McKay's view (1986) that economic activity is ultimately concerned with human welfare, not merely profit. In choosing to bid for an event, Lynch and Jensen (1984) advise that economic impact should constitute part of, but not the sole consideration for cities.

Economic impact studies have been used to gauge the success of specific events, calculate the economic benefits, or change in perception of the city as a result of hosting a mega-event (Barrios, Russell, and Andrews 2016; Clark 2008; Dwyer, Forsyth, and Spurr 2005; Fayos-Solá 1998; Lee and Taylor 2005; Malfas, Houlihan, and Theodoraki 2004; Matheson 2006; Richards and Wilson 2004; Soldo, Arnaud, and Keramidas 2013). In more recent years, though, an increasing number of voices have questioned the traditional equation of mega-event $=$ economic benefit. In particular, the 2015 book by Andrew Zimbalist, Circus Maximus: The Economic Gamble behind Hosting the Olympics and the World Cup, harshly confronts these arguments, arguing against cities investing in this strategy. Alongside the criticisms of other scholars (Coalter, Allison, and Taylor 2000; Flyvbjerg and Stewart 2012; Hall 2006; McGillivray and McPherson 2012; Müller 2015), Flyvbjerg and Stewart (2012), through a study from 1960 to 2012, have declared the Olympics as the most consistently over budget mega-project of all time.

In addition, there has been a response to calls for expanded thinking and research to the broader social impacts of events
(Getz and Page 2016). One example is the Impacts ' 08 and recently announced Impacts ' 18 report for the Liverpool 2008 ECoC, led by García (2010), is one of the most expansive mega-event impact and evaluation studies spanning over a decade. The reports cover issues of economics and tourism, but also local participation, image and perception, along with governance and delivery. The report stands as a strong example of a city deeply investigating the transverse impacts of an event and has served as a model for other host cities to follow. Despite this broad purview, little is generally said about the relationship between mega-events and the relevant planning efforts made to preserve a city's cultural heritage. Though not managed by event organizers, the Liverpool 2008 ECoC came to inspire several independent restoration projects throughout the city (Jones 2017).

\section{Governance and Planning for Mega-event Infrastructures}

Mega-events have long been associated with a mass impact on the built environment (Chalkley and Essex 1999; Essex and Chalkley 1998; Liao and Pitts 2006). The infrastructure of mega-events contributes largely to their overall cost and economic viability. If future Olympics reduce the amount of new infrastructure built for the events, as suggested by the IOC Agenda 2020, the entire economic equation could change, altering both their overall impact and potential viability. The infrastructure built can vary extensively between events. Typically, infrastructures utilized by Olympics and Expo, such as stadiums, sport venues, or exhibit halls are newly built. Additionally, transport networks and hubs also serve as key investments within the infrastructure of events (Bovy 2006). These investments are directly linked to the mass numbers of visitors the event intends to attract but also serve larger ambitions of the legacy of these events (Kassens-Noor 2012, 2013). The IOC has also included transportation as one of the areas of concern in the transfer of knowledge program, which facilitates learning between cities hosting the Olympics (Bovy 2008; KassensNoor 2013).

Another common theme arising from mega-event literature is their role in urban regeneration (Cornelissen 2004; Gold and Gold 2008; Hiller 2006). The latter happens both in terms of physical changes introduced to the city and in the image of the city projected. The London 2012 Olympics and subsequent redevelopment of East London is a highly cited successful, albeit contentious, ${ }^{1}$ example of using an event to complete a long intended transformation project (Davis and Thornley 2010; Ferm and Jones 2016). Newly built infrastructure is often not limited to structures required only for the event but includes investment in transportation networks including airports and highways, sometimes becoming the highest expenditures for an event. Promoters argue that expanding mobility networks allow visitors to reach the event, but also contribute to longterm growth. Mega-events can be seen as a specific phenomenon in the planning of cities that attempt, in a single period, to establish the future outcomes and developments of the city (Oity ex 2011; Short 2008). 
While cities often view these events as opportunities to realize projects on a fast-track schedule, the final products must meet set standards. The IOC regulates the plans for the Olympics while the FIFA provides particular specifications for stadiums built for the World Cup. These specifications can present certain difficulties in the reuse of stadiums for other sports and activities. The role of these external organizations raises questions of the suspension of the normal "rule of law" (Mule of 2015). The decision-making process for the entire city becomes narrowly focused on the event and can take priority over other activities (Clark 2008). The role of public participation and responsiveness in planning are issues often raised in the hosting of a mega-event (Andranovich, Burbank, and Heying 2001; Haxton 2003) but does not typically come to impact processes in any meaningful ways, in part due to the intended expediency of bypassing traditional planning mechanisms. As the overall economic equation of mega-events has come to be questioned, so has the strategy as a mass regeneration scheme (Brownill, Keivani, and Pereira 2013).

\section{Tourism Related to Mega-events}

Another key defining attribute of mega-events is the attraction of tourists. Both definitions quoted at the beginning of the literature review cite mass appeal and tourism as key aspects of a mega-event. The boom of attraction is of course the event itself, yet cities intend to craft a long-term appeal that continues to draw visitors long after the event finishes (Getz 2008). As tourism continues to expand globally United Nations World Tourism Organization (UNWTO 2011), it presents a cornerstone of the economic success of events. Tourism is often linked to the investments in infrastructure and physical regeneration, as well as through the new image of the city or place branding that can be promoted through the mass advertisement of a mega-event (Gold and Gold 2008). The event serves as both the mechanism for change and the stage from which to project it to the world. The role of tourism in mega-events has long been recognized, with studies by Ritchie and others appearing in the 1970s (Ritchie and Beliveau 1974; Ritchie and Smith 1991; Ritchie and Yangzhou 1987) that already warn of the potentially limited duration of events' touristic appeal.

Coming primarily from event and tourism studies, much of the literature has taken on the burden of "proving" the value of large-scale events through impact studies on local and national economies. These studies attempt to predict the profit of events based primarily on the number of expected tourists arriving specifically for the event and how much they will spend during their visit (Burgan and Mules 2000; Rees 2000). The short-term benefit of tourism is part the equation, though long-term changes in the influx of tourists are deemed the most important and can justify the expenses of hosting the event. However, it can be difficult to accurately study these trends over the long term (Faulkner 2003).

Many studies have come to question the reliability of tourism figures and the story they tell. In fact, despite the continued exertion that events attract great numbers of tourists, there is not a substantiated theoretical framework to explain motivations of visitors (Regan, Carlson, and Rosenberger 2012). Despite aims of developing a long-term attractiveness, these events tend to create a tourism bubble that is not matched following the close of the event (Falk and Hagsten 2017; Song 2010). Further investigations have also revealed that in some instances, the presence of a major event actually scares away some potential visitors (Fourie and Santana-Gallego 2011) or negatively impacts the number of visits to surrounding regions by "stealing" tourists that might have otherwise traveled to nearby areas.

Despite some insights into the political effects of megaprojects (Andranovich, Burbank, and Heying 2001), the current debate does not discuss one central issue. The typical supplyoriented arguments suggest that the existence of larger infrastructure for tourism derived from one mega-event (more attractive urban environments, more hotel rooms, etc.) will continue to attract tourists. To our knowledge, there is no investigation of how mega-events generate larger sets of actors selfinterested in promoting tourism and how this may be a relevant push over the following years. In other words, one can expect that a new political constituency of tourism-related stakeholders that the event generates may lobby for stronger protourism policies and urban investments to continue boosting this sector rather than others (Sykes and Brown 2015). This may be seen as a lock in for cities adopting the mega-event strategy and in our opinion should be studied in depth. For heritage, tourism has likewise become an increasingly important factor for continued conservation but also requires considered policies and promotion.

\section{Sociocultural Aspects of a Mega-event}

The normal activities and daily life of the city are subjected to incredible pressures, not only during the event itself but potentially for several years during the preparation period. It is difficult to comprehensively evaluate the range of impacts introduced by these events, which can range to include the environmental impacts of excessive litter or traffic (Mason and Beaumont-Kerridge 2004) to effects on local community groups (Bullen 2013). Hiller (2000) frames the mega-event as a social-class change of a place itself, typically displacing some of the existing populations and functions. Broader sociocultural and political aspects deal with social and governance issues which can be more deeply impacting than the purely economic aspect (Hall 1992). While some reports declare the production of a higher quality of life (Short and Kim 1999), others highlight the lack of community outreach and abandonment of portions of the population (Bullen 2013; Watt 2013). The perception of costs and benefits may vary between every actor and local resident as a community is not homogeneous (Faulkner 2003). Other research has broadened into the social realm using social exchange theory (Kim et al. 2015; Li, Hsu, and Lawton 2015; Waitt 2003) to understand changing perceptions and reactions of local residents where an event has been hosted. A significant debate has also considered the creation of 
new cultural identity and urban imaginaries through events (Elias-Varotsis 2006; Vanolo 2015). Some recent lines of research have even explored the potential for past venues of events to become recognized as heritage sites, given the value perceived by the local population (Kiuri and Teller 2015), such as the several already mentioned successful icons from past mega-events.

In the early 1990s, Bianchini and Parkinson (1993) connect mega-events to the cultural planning of cities, a theme continued to be discussed in the literature (Garcia 2005; Mooney 2004). Meanwhile, Benneworth and Duancey (2010) note the event as an opportunity for network capacity building with governance and broadening regional connections. With varying success rates, these events have also come to be incorporated into strategic plans of cities (Bramwell 1997). García and Cox (2013b) also found the London 2012 Olympic Games to contain a number of cultural activities as part of the preparation for the games, blurring the lines between sporting and cultural events. Within the previously mentioned ECoC program, several cases can be highlighted where the event was used to invest in and promote heritage such as in Genoa, Italy (Bonfantini 2015; Gabrielli 2005; Gastaldi 2016; Jones 2017) as well as missed opportunities as in the 2010 Istanbul (Jones 2015) or 1997 Thessaloniki (Deffner and Labrianidis 2005) where the event was not integrated into other city plans with projects not completed on schedule.

\section{Definition and History of Heritage Recognition and Protection}

Heritage is a wide-ranging term that can refer to the built as well as the unbuilt. The following sections aim at focusing on this topic from a planning perspective in how it has been defined and treated. The concept of heritage elevates a merely "old" object or place to the level of something considered historically meaningful. Yet the defining attributes of what qualifies a place or thing as heritage are not always clearly recognizable (Garden 2006). Bandarin (2008) even raises the question of what value heritage still has in a contemporary society. Scholars categorize heritage through preceding adjectives such as cultural, natural, tangible, intangible, built, or urban heritage. Olwig (2005) defines heritage as anything society considers as inherited from the past, denoting a very broad and all-encompassing understanding of heritage that includes found objects, traditions, or natural areas created or valued by previous generations.

Harvey (2008) likewise recognizes the role of contemporary society in defining heritage but sees it as "the process by which people use the past" in order to create a contemporary social identity (Ashworth, Graham, and Tunbridge 2007). This idea of using the past also infers a political nature to heritage with its constant change and evolution depending on its solvency. These postmodern, pluralistic understandings of heritage allow for near infinite possibilities of inclusion (Harrison 2013; Lowenthal 1998) and lie far from the original concepts that first drove the conservation movement under Morris and Viollet le
Duc in nineteenth-century England and France (Glendinning 2013; Jokilehto 1999; Naidoo and Littler 2005). These changes have been ascribed to shifts in society and economics, globalization, deindustrialization, the rise of the experience economy, and changing philosophical concepts of the twentieth century (Harrison 2013). Heritage concepts therefore continually evolve, drastically changing over time, not just in terms of the identification of an object, place, or tradition as heritage but in the base held beliefs informing those decisions.

For heritage, there has always been a requirement of a certain time lapse. The acceptable quantity of "oldness" can vary greatly between contexts, but over the last two centuries, this component has shrunk from hundreds or thousands of years to just a couple of decades in many instances (Glendinning 2013; Jokilehto 1999; Koolhaas 2004). In some places, the age requirement necessary to be deemed heritage is an established regulation, such as the fifty-year age rule in the United States. Though in many situations, the age requirement is not a steadfast number but determined by the preexisting context. For example, a city with ancient monuments may struggle to equally value 200 -year-old industrial structures that might be highly prized elsewhere.

One also may notice that different traditions influence the development of geographically varied schools and approaches, inducing radically different conceptions of what constitutes heritage. While the perceived age requirement has reduced drastically in many locations, the possible held values, which crucially dictate what is or is not valued, have exponentially expanded. These differences have led to many of the conflicts within the conservation movement both in terms of identifying heritage and the method for protecting heritage. For many, such as Harrison (2013) and Lowenthal (1998), the potential exists for anything and everything to be heritage.

In his groundbreaking The Modern Cult of Monuments, Riegl (1903) recognizes and attempts to classify many of the competing values into two categories, that of memorial value and present-day value (Bandarin and Van Oers 2012; Glendinning 2013; Jokilehto 1999; Riegl 1903). Prior to Riegl, many practitioners focused on a single value (e.g., ideal beauty) that for them served as the primary determining aspect of heritage. Alternatively, Viollet le Duc, a French architect, was the leading promoter of stylistic restoration in the nineteenth century, arguing that any work must respect the authenticity of the original style and design more than the currently existing condition of a structure (Jokilehto 1999). This view granted much freedom to the restorer to reinvent or dramatically add to the original composition, as long as it respected the original style and offered a state of completeness. However, much of the contemporary thinking and approach to conservation has developed as a reaction against the work of Viollet le Duc. Following the mass destruction of WWII, Riegl's concepts, along with those of influential Italian mid-century architects and conservationists such as Leonardo Benevelo and others (Magrin 2015), came to form the basis of international charters dedicated to the protection of built heritage (Bandarin and Van Oers 2012). 
The 1964 Venice Charter is the first international document declaring protected monuments and sites as a common heritage recognizing the unity of human values (the International Council on Monuments and Sites [ICOMOS] 1964). The idea of common heritage then becomes the basis for world heritage, embodied in the World Heritage List and established in the 1972 Convention concerning the protection of the world cultural and natural heritage (the United Nations Educational, Scientific and Cultural Organisation [UNESCO] 1972). Sites or single works eligible for this status must be considered of "outstanding universal value from the point of view of history, art or science" (UNESCO 1972). While the 1972 document does not provide a precise definition of outstanding universal value, it lists a range of valuings including age and artistic. Though this definition created by an international body allows for these multiple value systems, it effectively creates a new value system where the title of World Heritage Site (WHS) becomes a value in and of itself and retains the role of international experts in defining and selecting heritage sites (Meskell 2012, 2013).

Beyond a Euro-centric history, Page and Mason (2004) discuss the development of preservation in America. While traditionally several anecdotes have been used to explain the birth of the movement, they describe it as a process developing over the last two centuries in diverse ways at local levels, connected to social reforms, and maintaining a complex relationship to economic development. While other traditions of preservation also developed, such as the Awqaf system in Islamic countries, international organizations, charters, and practices have spread globally to serve as important actors and tools in preservation practice (Aygen 2013).

\section{The Urban Governance, Planning, and Design of Heritage}

During the twentieth century, there has been a massive expansion within the conservation movement from a focus on the single monument to entire urban and cultural landscapes. The idea of urban landscape broadens the way the city is perceived, deriving from the thinking of townscape (Cullen 1961; Larkham 1996), and eventually leading to the historic urban landscape (HUL; Bandarin and Van Oers 2012). The concept of landscape borrows the terminology of a natural environment to enforce this understanding of the city as a continuous composition and not merely a series of unconnected components. Within conservation, historic urban areas were for many years valued only as the context or background of a monument. As described in the 1931 CIAM Athens Charter and the 1964 Venice Charter, the primary value revolves around singular architectural structures or monuments. Without this key focal point, the larger urban area was not recognized of its own accord (Athens Charter 1931; ICOMOS 1964). Officially, this view changes in 1987 with the Washington Charter, but earlier (particularly Italian) scholars formulated and put into practice these new concepts of urban heritage (since the 1960 Gubbio Charter for historic city centers). This new concept of landscape was important because it introduced, for the first time, a broader understanding of place and of urban heritage.

These ideas appear earlier in Gustavo Giovannoni's work, one of the first to recognize the value of minor architecture in Venice in 1910, where he recognized that no grand monument was required to value and protect an area as urban heritage (Bandarin and Van Oers 2012; Glendinning 2013; Jokilehto 1999; Veldpaus, Pereira Roders, and Colenbrander 2013). The 1964 Venice Charter also recognizes the expanding focus from the single monument to entire city districts or centers. In trying to conceive of a place as a whole, no longer do the physical aspects alone define a space. The social composition, including the residents themselves, traditional uses of the area, and the customary cultural practices form the intangible aspects that powerfully contribute to the quality as well as authenticity of a place. Some of these qualities will eventually come to be recognized as intangible heritage in their own right, often specifically linked to a particular location.

Initiated in 2005 with the Vienna Memorandum, the latest recommendation produced by the UNESCO is the HUL in 2011. On one hand, it reenvisions the way in which to understand the areas of urban heritage within the city as a whole, while also operating as a management tool (Bandarin and Van Oers 2012; Veldpaus, Pereira Roders, and Colenbrander 2013). It represents the evolution from the protection of the historic district/quarter to the historic town or historic center and finally the idea of the historic city. While these terms are often used interchangeably, they differentiate between viewing heritage as a single entity existing independently from the city versus an integrated piece woven into the larger urban forms and functions. Through reseeing the city as a landscape, all aspects are interconnected and in relation to one another (Jokilehto 2010). The historic city is composed of a number of landscapes that comprise the whole, including the contemporary additions. Through the HUL approach, the heritage areas of a city are not to be dealt with differently or separately from the rest of the city, in many respects a radical shift from the traditional approaches to the protection and management of heritage with strict boundaries separating heritage from everything else in one given place. While international bodies like UNESCO do not exercise direct control over heritage sites, since the second half of the twentieth century, they have come to exert a transnational level of influence over preservation practices and policy (Meskell 2013).

\section{The Urban Economics of Heritage and lts Politics}

Beyond conserving urban heritage out of a sense of obligation or due to ideological and political motivations, public decision makers and private investors have also valued and conserved heritage as an economic asset (Rizzo and Throsby 2006). Pietro Gazzola, one of the drafters of the Venice Charter and first president of ICOMOS, expressed concern over the increasing role of economics and tourism in determining the value of sites with the release of the 1976 Recommendation and creation of the World Heritage List (Glendinning 2013; Jokilehto 1999). 
Journal of Planning Literature 33(4)

The addition to a national heritage list or gaining status as a WHS can be a major draw (Willems 2014), often with tourism implications. The WHS label in particular is now internationally recognized as the highest standard for historic places, though the exploitation of heritage for economic gain though is not a modern concept. For example, the column of Marcus Aurelius in Rome became a tourist attraction during the middle ages, offering Pilgrims a better view of the city (Jokilehto 1999). Tourism as a driver for conservation takes many forms, an extreme example being the massive restoration and reconstruction works necessary to create Colonial Williamsburg during the mid-twentieth century (Fitch 1990).

Many studies have specifically examined the correlation between heritage designation and property values. Already by the 1990s, particularly in the United States, scholars expressed significant concern that designating residential areas as heritage areas would increase property values (Gale 1991) - forcing out lower income residents. Since then, many studies have found that property values were at least maintained and usually did increase following preservation (Asabere and Huffman 1991; Mason and De la Torre 1999; Leichenko, Coulson, and Listokin 2001; Mason 2005; Mason and De la Torre 1999; Rypkema 1994, 2012; Rypkema, Cheong, and Mason 2013). Additional tax credits in the United States since the 1970s have encouraged private owners to restore their properties (RybergWebster 2013, 2015), leading to an incremental process of revitalization (Ijla et al. 2011; Ryberg-Webster and Kinahan 2014). Some studies have found that even neighboring areas benefit from the listing of nearby historic areas as they come to be associated with their quality and standards (Lichfield 1997). Researchers have used varying methods to measure the value of heritage areas depending on the intended use of structures, their condition, tourism accessibility, and so on (Lichfield 1988; Serageldin 1999; Squire and Van der Tak 1975). Overall, the literature strongly presents the argument of conserving and promoting built heritage as a smart economic choice and serves as a valid reason to preserve (Listokin, Listokin, and Lahr 1998; Mason 2005; Wolf, Horn, and Ramirez 1999).

However, a key question remains: who does benefit most from a profitable heritage? While higher property values may result in a higher collection of taxes, it can require higher upkeep standards for owners who may be difficult or in some cases impossible to meet (Coulson and Leichenko 2001). Actual preservation efforts may also be relegated to a secondary position in comparison to reaping economic benefits (Stough 1994). The situation can then often end up with economists and preservationists on opposing sides instead of finding common ground, working toward a strategic outcome (Mason 2008). The threat in focusing on economic goals also risks transforming vibrant lively zones being conquered and sanitized through policies for touristic purposes. In Ruggles' (2012) opinion, tourists should not be recognized as stakeholders due to their transient involvement in a place and should therefore not take a priority in decisions determining the city. Taken to the furthest extremes, however, this view could limit access to protected areas only to local residents, impairing universal values of heritage appreciation. In addition, it would be unrealistic not to consider the political pressure exerted by tourism-related interests and organizations.

Urban renewal and/or regeneration often serve as another desired outcome of recognizing and protecting historic areas (Kupka 2012; Papanikolaou 2012; Pereira Roders and van Oers 2011). As Mason (2004) states, there has always been a hope that heritage has the power to transform. While urban development and preservation have at times been considered as opposing forces, Attoe (1979) early on recognized the opportunity for the two fields to work toward shared goals. While traditional approaches of urban renewal have been quite drastic and often involve near total reconstruction of areas, conservation can be an alternate, more considerate approach. Kupka (2012) defines varying approaches to conservation as an urban development tool in differing cultural contexts. He describes the driving motivation for urban development to be either economically oriented, in order to attract tourists, intended to develop further cultural activities, or to strike a balance between development and restrictive conservation. This economic valuing of heritage falls within the larger trend of cities economizing culture (Rizzo and Mignosa 2013; Rizzo and Throsby 2006; Scott 1997; Throsby 1997, 2001). Using conservation as a tool of urban redevelopment can be a way to reactivate portions of the city instead of resorting to unrestrictive growth (Ponzini 2009). If we were to consider this within the context of a mega-event, we could foresee the regenerative intentions of a mega-event combined with existing heritage assets to develop a long-term process of transformation rather than mega-events investing solely in new infrastructures.

\section{Heritage Tourism}

Cultural tourism is currently the world's largest service industry (Schröder-Esch 2006; Timothy and Boyd 2003) and heritage tourism has become a major-and ever expanding (UNWTO 2011) - component with many cities and countries in competition to attract visitors (Chang et al. 1996). The economic benefits of tourism are among the primary reasons for utilizing heritage to attract visitors. This income can provide additional revenue to fund conservation projects and also provide incentive to continue protecting sites (Ashworth and Larkham 1994). Yet tourism is also noted for the many negative impacts, it can have on a city. Tourism promotion is not primarily geared toward the needs of local residents (Healy 1992; Nasser 2003) and can drastically change the native character of a place through marketing goods and services toward tourists, not residents, often resulting in increased living costs (Ronström 2014) and calls for more sustainable and resilient heritage tourism (Manrique, Jamal, and Warden 2016).

These developments also lead to the loss of authenticity, the very attribute many tourists claim to be seeking and conservation policies aim to protect (MacCannell 1976; Ruggles 2012). Venice is one of the clearest examples of the impact tourism can have on a historic city. The current number of permanent inhabitants living in the city is less than the number of daily 
tourists (Grabar 2014). The majority of stores are oriented toward the needs of tourists, not local residents, and the price of real estate has become so excessive that many residents can no longer afford to live in Venice itself (Russo 2002). It draws millions of visitors a year, but ironically very few remnants of nontouristic Venetian urban life now remain, one result being that the millions of visitors do not acquire an actual understanding of the heritage they visit (Settis 2014).

If not careful, policies enacted to promote tourism can lead to a monoculture of areas or entire city centers (Russo 2002; Van der Borg and Russo 1999), potentially erasing the original qualities that attracted visitors in the first place. While the reasons behind heritage tourism can vary greatly (Poria, Butler, and Airey 2003), ultimately, tourism occurs because of an intentional management, planning, and marketing by cities (Nuryanti 1996). Tourists need to be aware of a place to visit and have likely previously built some preconceived expectation of what they intend to find. Therefore, in terms of tourism, there is also a global-local condition that balances between the needs of local inhabitants and international visitors (Chang et al. 1996), in many ways, similar to mega-events. While tourism is by no means the only expected return that motivates cities to conserve urban heritage, it has come to represent a major component in the heritage equation.

\section{The Sociocultural and Anthropological Ramifications of Heritage}

Much of the original preoccupation with the idea of authenticity during the eighteenth and nineteenth centuries dealt with the physical qualities of a monument or structure. The early conservation movement began with a renewed interest and fascination in antiquities. However, the twentieth century broadly expanded thinking on heritage, particularly with the 1994 Nara Declaration on Authenticity, which took broad steps in reinterpreting the long-held traditional understandings of authenticity (Bandarin and Van Oers 2012; Glendinning 2013; ICOMOS 1994). Intended to include non-Western traditions of culture, the declaration replaces the Venice Charter's hard lined requirements on the authenticity of physical materials with a more flexible, cultural, contextually based determination of heritage and authenticity (ICOMOS 1994). The international community now recognizes certain practices, such as the traditional disassembling and reconstruction of the Ise Grand Shrine, as authentic, even though the original, physical elements no longer exist. Glendinning (2013) raises concerns that the physical authenticity of structures is at risk of becoming an optional "extra" in contemporary preservation. Ruggles (2012) condemns preservation itself for creating inauthentic historic urban spaces. Noted architect and theorist Rem Koolhaas (2004) ironically suggests that all urban fabric, even the yet unbuilt, should be entirely conserved in order to have a truly authentic experience of the urban realm. While hyperbolic and ridiculous, this approach would merely extend the rhetoric of authenticity to its furthest conceivable extents.
Discussions on authenticity appear also in the classic works of Jacobs (1961) and continue through those of Zukin (1995, 2009) that lament the loss of authenticity in public spaces. However, Appleyard (1979) notes that it is in fact people like Jacobs whom have in part contributed to the loss of authenticity through the displacement of the previous tenants from areas like Greenwich Village. Pereira (2007) notes the discussion on authenticity actually refers to a preferred state of being, not one that is in some way more "real" or "true" than the present existing condition. The current setting, regardless of its qualities, is always the most authentic. Garden (2006) argues that authenticity has been wrongly identified as a quality by which to define the past, though it has become an integral part of the process.

Despite the stated desire for an "authentic experience," most tourists are instead interested in having their preconceived ideas of heritage confirmed (MacCannel 1976; Appleyard 1979; Aygen 2013; Barthel 1996). Simulacra have become an increasingly used approach in presenting historic areas where the past is reenacted for the sake of tourists (Aygen 2013). This simplified representation of history itself may be for educational or purely entertainment reasons, but the authenticity of the story being presented may be altered to tell a particular version tailored for political reasons or to suit a particular audience. Educationally focused presentations may sanitize the true harsh reality of a place in order to make it family friendly (Barthel 1996). The problem then arises of authenticity no longer being a quality inherently found within the historic area itself, but one to be determined by the user (consumer) of the place (Barthel 1996; Nasser 2003). Therefore, in spite of preservation's near dogmatic pursuit of authenticity, the results contradict the original goals and now instead seek to present the most authentic replica (Aygen 2013). Chinese historic cities have recently witnessed a significant trend in this direction (Zhang 2008). Beyond the issue of authenticity, the values associated with heritage are becoming increasingly pluralistic (Avrami, Mason, and De la Torre 2000; Mason and Avrami 2002; Mason and De la Torre 2000), resulting in an increased expectation of a functional or productive heritage.

Some of the expanding expected functions of heritage have been as a tool to address social problems or encourage development (Matero 2011; Pereira Roders and van Oers 2011). Scholars (Pendlebury, Townshend, and Gilroy 2004; Townshend and Pendlebury 1999) and international institutions have called for increased public engagement and inclusion of local citizens within the planning processes of heritage conservation. UNESCO has been calling for public participation in decisionmaking practices for over a decade through the Strategic 5C's (UNESCO 2002, 2007) and again emphasized in the report on Culture for Sustainable Urban Development for the 2016 Habitat III conference (UNESCO 2016). The European Union has also funded the Community-led Urban Strategies in Historic Towns initiative to provide resources for cities to include local citizens in decision-making (Neagu et al. 2017). However, these initiatives are not solely socially motivated, but also intend to benefit cities economically as well (Silberman 
2014), and can be therefore reconnected to the criticisms described in previous sections.

\section{General Considerations on the "City Link" of Heritage and Mega-events}

Protecting entire urban areas introduces both new concepts to conservation and methods. When discussing a single structure, the responsibility or obligation to preserve is typically more clearly defined in regard to whose jurisdiction the property falls within or who is financially responsible (Fitch 1990). With the protection of entire districts, towns, or city centers, however, the need for additional approaches to conservation becomes evident. Already in the 1970s, Appleyard (1979) recognizes the common trend of gentrification occurring in and around preserved urban heritage areas. Formal conservation regulations regarding materials to be used and techniques of preservation have no capacity to address the broader social and economic consequences on an area. With the increasing recognition of people and activities in the 1976 Recommendation, new tools such as social preservation are introduced. Social preservation focuses on protecting the inhabitants of historic areas, ensuring they are not forced from their homes due to exponential increases in rent. Therefore, various policies and rent controls are put in place to mitigate unintended consequences of conservation (Appleyard 1979). However, one detriment to this approach is the restriction of potential economic boost from heritage that has become one of the motivating incentives for both private and public entities to invest in conservation of historic areas (Mason 2008; Wojno 1991).

The recently introduced HUL approach attempts to encompass these broadened issues relating to heritage and provide a new management approach to not just historic quarters or districts but the entirety of the historic city. The historic city is conceived of as a layering of "cultural and natural values and attributes" and "considers cultural diversity and creativity as key assets for human, social and economic development" (Bandarin and Van Oers 2012, 212-213). A management tool based on urban landscape principles (Veldpaus, Pereira Roders, and Colenbrander 2013), the goal of this approach is to reintegrate historic areas into the larger functions of the city as productive, active, and lively places once again, not mere stage sets for tourists (Bandarin and Van Oers 2012; Rodwell 2012; Veldpaus, Pereira Roders, and Colenbrander 2013). HUL suggests the inclusion of additional tools including surveys and mapping, participatory planning processes, and developing local management frameworks (Bandarin and Van Oers 2012). It positions itself as a response to the many unforeseen changes heritage has been required to address over the last fifty years from the increase in mass tourism, unprecedented development of cities, climate change, and globalization. Additionally, it tries to address the shortcomings in previous conservation theory that has in some ways contributed to heritage areas becoming isolated islands within cities (Bandarin and Van Oers 2012). Time has yet to determine the effectiveness of the HUL approach in practice. However, it can be considered as a possible conceptual step toward connecting heritage to megaevents - as part of contemporary cities' activities.

The promoted shift in Agenda 2020 on the part of the Olympics reveals as well a significant change in how mega-events come to be thought about and planned. The Olympics and Expos have often remained on the outskirts of cities with sites planned as a platform that hosts the various venues, separate from the immediately surrounding context. This approach has in many ways simplified the planning of a mega-event but has proven to be massively expensive and unsustainable. Megaevents' link to particularly in historic- and heritage-rich cities has barely had any explicit theorization, despite being a pressing issue in practice. Mega-event debate and policy making may gain from cultural mega-events, such as the $\mathrm{ECoC}$, that have long been integrated within the fabric of cities.

\section{Conclusions}

At first glance, mega-events and heritage may not appear to have an obvious overlap. However, our literature review-deepening in particular the historic evolution of the two policies and their current economic, infrastructural, tourism, and sociocultural dimensions - reveals they in fact approach and face similar urban issues. Due to contrasting perception of respective positions of heritage preservation and mega-event management - as the first being merely conservative and the second basically being boosterist - there is limited common reflection. The literature review explains their different origins, the nuanced theoretical positions, and yet the limited crosscutting perspectives in practice. After explain the other reasons why this disconnect exists, we highlight four critical issues that the two fields have in common: focus on externalities and secondary effects rather than on the policy targets alone; urban and political dynamics that connect the matter to mass tourism; relevance of public expenditure; and the transnational features of both mega-events and heritage preservation policies in current times. This realization could have significant impacts for both fields, therefore we suggest concrete grounds where these overlaps can be further studied in theory and tested in practice.

\section{Why This Disconnect Has Persisted in Practice and in Literature}

Mega-event and urban heritage policies are difficult to join as they are generally perceived as belonging to different realms. What are the reasons behind this division? Based on the literature review, we identify five issues: the potentially conflicting goals and approaches between mega-event planning and heritage preservation; certain tunnel vision in both fields; focus on sport mega-events rather than cultural ones; long-term postevent considerations are limited in the first field and vital in the second; and the traditions of study have evolved differently over time.

First, mega-events are highly ambitious in terms of growth. On the other hand, heritage efforts have often been framed as 
opposing change and development by critics and might not naturally be viewed as a potential asset to mega-events or vice versa. Both literatures are quite broad and expansive and they cover similar issues, but they do so in insular ways, without exploring and benefiting from the links to one another.

Secondly, research scopes and methods do not converge. As noted by Ryberg-Webster and Kinahan (2014), there is a particular level of tunnel vision within the preservation field. There is an extreme specialization within the field due to the highly technical nature of preservation practice (e.g., related to physical/architectural matters). Heritage is more often than not viewed from within the field as under threat from new developments rather than emphasizing the potential benefits of certain degrees of consistency with the past. Many studies conducted on mega-events also have resulted in a type of tunnel vision where these events are valued solely for their ability to provide an economic contribution. Studies that look to changes beyond the economics due to the event often come primarily from the social sciences and rely on questionnaires, reviews of newspapers, media, and social media coverage. These investigations do not go in depth to the actual physical/architectural changes that may have occurred but capture rather just the impressions of those changes.

A third reason is connected to the fact that the most studied events are by far the Olympics and Expos. As these events have tended toward being separated from the city, their specific connection to the city and heritage has been, so far, a link often overlooked. While newly built infrastructure related to events (e.g., airports, iconic structures) is another largely covered topic. Often, these interventions are not directly related to consolidated areas of the city and even less to heritage sites.

Fourth, there is a time-frame mismatch between the two research fields. Mega-events are popular topics to cover in the years leading up to them and during the host year itself. Therefore, much of the research contemplates potential impacts, but rarely is there an equivalent long-term analysis following the close of these events (with the notable exception of Impacts 08, see García, Melville, and Cox 2010). On the contrary, longterm considerations are central in heritage studies and practices.

Finally, as explained in second section, the distance between the two fields derives from greatly different traditions of studies, though today the urge for filling the gap both in theory and in practice is ever more visible. While past studies such as the special edition in the International Journal of Heritage Studies (Gammon, Ramshaw, and Waterton 2013; Pinson 2016) has considered the role of Olympic sites as heritage sites, this review has shown a greater network of connections between mega-events and heritage to be further considered. Besides the general intention of this article of showing the urgency of the link between the two fields in practice, second section of this review explains that potential bridges are not particularly difficult to be drawn between these subjects, as their literatures tend to parallel in covering similar and comparable aspects.

\section{Next Steps for Practice, Policy, and Research}

The focus on externalities and secondary effects rather than on the primary policy targets alone connects the two policy fields, as does the aim of attracting tourists. These are the first two overlaps we consider. Mega-events such as the Olympics and Universal Expo/World's Fair began as efforts to bring together nations in friendly competition or to promote the latest technological innovations. Yet these events have taken on other purposes, primarily as tools of urban development and regeneration, often following a pro-growth rationale, in most cases, linked to mass tourism. The recognition and protection of built heritage was originally based on the need to conserve ancient monuments that would be otherwise lost. While those tenets remain at the core of the preservation movement, it has now also become a key part of many city's tourism strategies or to increase property values for listed historic areas. This motivates many renewal project and heritage-led regeneration policies. At their core, they have both become key assets to cities and play a role in strategies to promote and improve cities, staples of regeneration approaches. In essence, both are expected to deliver or produce amenities and environments for cities in order to attract and retain masses of tourists.

Thirdly, significant public expenditure is justified by the expectation of generating adequate returns in terms of side economic effects. The events' expanded budgets, hard deadlines, and legal work-arounds that allow ambitious urban goals ease the expenditure as does appreciating heritage for communication and promoting parts of cities as desirable places to live, work, visit, and where to consume. The two public policy fields' overlaps, synergies, and inconsistencies need to be further investigated under an urban perspective.

Fourth, both approaches to urban policy making and development have become transnational strategies. International bodies set particular requirements and standards for both mega-events and heritage that must be met and followed - for example, the IOC, UNESCO's World Heritage Centre. Preexisting frameworks are simultaneously adapted to and exert homogenizing pressure on a diversity of contexts with vastly different cultural, social, and governance structures. However, this transnationality does not necessarily imply that there is an inherent learning that passes between similar cases (Degen and García 2012; Grabher and Thiel 2015; Lauermann 2014), neither from planning initiatives for mega-events to heritage preservation (or vice versa) nor is much learning derived from the overlapping fields of practice (most notably, cultural megaevents). Understanding the transnational mobilities of policy ideas, planning tools, and actors seems a promising perspective for research.

More generally, the significance of this existing overlap between mega-events and heritage preservation resides in the possibility to connect them, further integrate them into (and learn from) one another for their mutual benefit. If aware of their planning and sociocultural dimensions, mega-events could be in dialogue with preservation tools and not simply try to escape the city fabric or bypass regulations. By integrating 
events into existing fabric and reusing structures, built heritage could benefit greatly. Yet it would also work to address the recent difficulties facing the Olympics and other large events, namely their mass expenses and limited long-term benefit to cities. In addition to cities questioning the dynamics of hosting a mega-event, the literature also has come to question the longheld economic and tourism models promoted by past research and proponents of mega-events. The review also reveals the susceptibility of heritage areas where even the most wellmeaning policies have had adverse consequences in terms of endangering authenticity, boosting mass tourism, and inducing gentrification.

An approach that combines these two realms could "rebrand" mega-events (most notably the Olympics) from being seen as overly bloated, unnecessary expenses that are not justified in the long term to more sustainable, low-impact events that have a broader range of impacts that are noticeable within the city itself. Innovative ways to embed events within the city fabric itself may lever in a sustainable manner the cultural and symbolic power of these historic spaces and icons of the city as a part of the event.

Instead of simply waiting for responding to future problems, theoretical and literature-based debates could anticipate urban issues that will become more and more common. A key starting point can be the relatively less studied mega-event dealing more intensively with cultural heritage: the $\mathrm{ECoC}$. The ECoC is a yearlong cultural program consisting of a series of cultural activities situated throughout the city and is one of the longest running continuous EU policies and the flagship cultural program for the European Commission (European Commission 2014). Operating annually since 1985 , over fifty cities throughout Europe holding the much-coveted title of ECoC, with typically two cities cohosting each year (García and Cox 2013a). Many cities having UNESCO sites have hosted or will host the ECoC and they can provide relevant evidence to both study long-term effects and potentially implement research findings. For many cities, the ECoC has acted as the tool to create a new identity for the city (Ponzini and Jones 2015). Several of the cities have in fact chosen to highlight their historic nature in their event, including Thessaloniki 1997, Weimar 1999, Avingon 2000, Graz 2003, Genoa 2004, Istanbul 2010, and Tallinn 2011, among others (García and Cox 2013a). By advertising themselves primarily as historic cities, they positively promote themselves as a place in which to live and work. This imagery may be intended to attract not just tourists but also long-term residents and creative producers (Bandarin, Hosagrahar, and Sailer Albernaz 2011; Rodwell 2013). This existing megaevent evidence can come to serve as an example to be studied for planning other sorts of events in more context-and-heritagesensitive manners. Similar, but less developed international and national programs can be interesting to study as well, among others: Culture City of East Asia, Arab Capital of Culture, American Capital of Culture, Ibero-American Capital of Culture, UK City of Culture, Italian Capital of Culture, and so on.
Though not focused specifically on heritage-related issues, a number of important research studies have already been conducted on the ECoC. Official reports for the European Commission have been conducted by Palmer/RAE Associates (2004) and García and Cox (2013a). These studies provide valuable quantitative statistics of the program as a whole and how different cities have used the event. Sykes (2011) edited a special edition of Town Planning Review that provided an indepth look into the program with a number of case studies. While most cities have created a postevent evaluation, one of the most holistic and in-depth reports is the abovementioned Liverpool Impacts 08 report led by García (2010).

More research will be necessary to find the mutual benefits and risks across mega-events and built heritage policies and critically investigate the city (in its economic, planning, and sociocultural dimensions) as the missing link between them. There are good theoretical and practical reasons to do so and there is substantial amount of evidence to yet investigate.

\section{Author's Note}

Part of this article was originally conceived and produced as an element in the PhD dissertation by Zachary Jones, entitled "Synergies and frictions between mega-events and urban heritage in the European Capital of Culture program: A comparative study of Genoa 2004, Liverpool 2008 and Istanbul 2010". The authors jointly synthesized and developed further these ideas in the final form of this article, also thanks to the comments received from anonymous reviewers.

\section{Declaration of Conflicting Interests}

The author(s) declared no potential conflicts of interest with respect to the research, authorship, and/or publication of this article.

\section{Funding}

The author(s) received no financial support for the research, authorship, and/or publication of this article.

\section{Note}

1. See Ferm and Jones (2016), Raco and Tunney (2010), and Watt (2013) for a discussion on the negative social side effects for some local residents and businesses. See, for example, Raco (2014, 2015) regarding London 2012 urban governance issues.

\section{References}

Andranovich, G., M. J. Burbank, and C. H. Heying. 2001. "Olympic Cities: Lessons Learned from Mega-event Politics." Journal of Urban Affairs 23 (2): 113.

Appleyard, D. 1979. The Conservation of European Cities. Cambridge: MIT Press.

Archer, B. H. 1982. "The Value of Multipliers and Their Policy Implications." Tourism Management 3 (4): 236.

Asabere, P. K., and F. E. Huffman. 1991. "Zoning and Industrial Land Values: The Case of Philadelphia.” Real Estate Economics 19 (2): 154-160.

Ashworth, G., B. Graham, and J. Tunbridge. 2007. Pluralising Pasts: Heritage, Identity and Place in Multicultural Societies. London, UK: Pluto Press. 
Ashworth, G. J., and P. J. Larkham. 1994. "A Heritage for Europe: The Need, the Task, the Contribution." In Building a New Heritage: Tourism, Culture and Identity in the New Europe, edited by G. J. Ashworth and P. J. Larkham, 1. London, UK: Routledge.

Athens, C. 1931. "The Athens Charter for the Restoration of Historic Monuments." In 2004. International Charters for Conservation and Restoration, edited by M. Petzet and J. Ziesemer, 31-36. Paris: ICOMOS.

Attoe, W. O. 1979. "Historic Preservation." In Introduction to Urban Planning, edited by Anthony J. Catanese and James C. Snyder, 297. New York: McGraw-Hill.

Avrami, E., R. Mason, and M. De la Torre. 2000. Values and Heritage Conservation: Research Report. Los Angeles, CA: The Getty Conservation Institute.

Aygen, Z. 2013. International Heritage and Historic Building Conservation: Saving the World, vol. 3. New York: Routledge.

Bandarin, F. 2008. "The Conservation Predicament in the Age of Globalization: Heritage Values Today and Tomorrow." Presented at the 4th Dinos Leventis Memorial Lecture, Nicosia, Cyprus.

Bandarin, F., J. Hosagrahar, and F. Sailer Albernaz. 2011. "Why Development Needs Culture." Journal of Cultural Heritage Management and Sustainable Development 1 (1): 15.

Bandarin, F., and R. Van Oers. 2012. The Historic Urban Landscape: Managing Heritage in an Urban Century. Oxford, UK: WileyBlackwell.

Barrios, D., S. Russell, and M. Andrews. 2016. Bringing Home the Gold? A Review of the Economic Impact of Hosting Mega-events. Cambridge, MA: Center for International Development, Harvard University.

Barthel, D. 1996. "Getting in Touch with History: The Role of Historic Preservation in Shaping Collective Memories." Qualitative Sociology 19 (3): 345.

Basso, M. 2017. Grandi eventi e politiche urbane: Governare "routine eccezionali" un confronto internazionale. Milan, Italy: Guerni e Associati.

Benneworth, P., and H. Dauncey. 2010. "International Urban Festivals as a Catalyst for Governance Capacity Building." Environment and Planning C: Government and Policy 28 (6): 1083.

Bianchini, F., and M. Parkinson. 1993. Cultural Policy and Urban Regeneration: The West European Experience. Manchester, UK: Manchester University Press.

Bonfantini, G. B. 2015. "Historic Urbanscapes for Tomorrow, Two Italian Cases: Genoa and Bologna." European Spatial Research and Policy 22 (2): 57.

Bovy, P. 2006. "Solving Outstanding Mega-event Transport Challenges: The Olympic Experience." Public Transport International 6 (6): 32 .

Bovy, P. 2008. "Olympic Games Transport Transfer of Knowledge.” HITE-Greek Society of Traffic Engineers 156: 1-13.

Boyle, P., and K. D. Haggerty. 2009. "Spectacular Security: Megaevents and the Security Complex." International Political Sociology 3 (3): 257-74.

Bramwell, B. 1997. "Strategic Planning before and after a Megaevent." Tourism Management 18 (3): 167.

Brownill, S., R. Keivani, and G. Pereira. 2013. "Olympic Legacies and City Development Strategies in London and Rio: Beyond the
Carnival Mask?" International Journal of Urban Sustainable Development 5 (2): 111.

Bullen, C. 2013. A Comparison of Liverpool (UK) and Marseilles (France). European Cultural Foundation.

Burgan, B., and T. Mules. 2000. "Event Analysis: Understanding the Divide between Cost Benefit and Economic Impact Assessment." In Events Beyond 2000: Setting the Agenda, edited by John Allen, Robert Harris, Leo K. Jago, and A. J. Veal, 46-51. Sydney, Australia: Australian Centre for Event Management.

Carlsen, J., G. Soutar, and D. Getz. 2000. "Pre- and Post-event Evaluation Criterion Research.” In Events Beyond 2000: Setting the Agenda, edited by John Allen, Robert Harris, Leo K. Jago, and A. J. Veal, 76-84. Sydney, Australia: Australian Centre for Event Management.

Chalkley, B., and S. Essex. 1999. "Urban Development through Hosting International Events: A History of the Olympic Games." Planning Perspectives 14 (4): 369.

Chang, T. C., S. Milne, D. Fallon, and C. Pohlmann. 1996. "Urban Heritage Tourism: The Global-local Nexus." Annals of Tourism Research 23 (2): 284.

Claes, A. 2013. "The 10 Biggest Music Festivals in the World." Accessed September 25, 2015. http://www.mtviggy.com/lists/the10-biggest-music-festivals-in-the-world-2/.

Clark, G. 2008. Local Development Benefits from Staging Global Events. Paris, France: Organisation for Economic Co-operation and Development (OECD).

Coalter, F., M. Allison, and J. Taylor. 2000. The Role of Sport in Regenerating Deprived Urban Areas. Edinburgh, UK: Centre for Leisure Research, University of Edinburgh, The Scottish Executive Central Research Unit.

Cornelissen, S. 2004. "Sport Mega-events in Africa: Processes, Impacts and Prospects." Tourism and Hospitality Planning \& Development 1 (1): 39.

Coulson, N. E., and R. M. Leichenko. 2001. "The Internal and External Impact of Historical Designation on Property Values." The Journal of Real Estate Finance and Economics 23 (1): 113.

Cullen, G. 1961. The Concise Townscape. London, UK: Routledge.

Davis, J., and A. Thornley. 2010. "Urban Regeneration for the London 2012 Olympics: Issues of Land Acquisition and Legacy." City, Culture and Society 1 (2): 89.

Deffner, A. M., and L. Labrianidis. 2005. "Planning Culture and Time in a Mega-event: Thessaloniki as the European City of Culture in 1997." International Planning Studies 10 (3): 241-64.

Degen, M., and M. García. 2012. "The Transformation of the 'Barcelona Model': An Analysis of Culture, Urban Regeneration and Governance." International Journal of Urban and Regional Research 36 (5): 1022-38.

Dunstan, G. 1986. "Living with the Grand Prix: Good or Bad.” In The Adelaide Grand Prix: The Impact of a Special Event, edited by J. P. A. Burns, J. H. Hatch, and T. J. Mules, 105-23. Adelaide, Australia: Centre for South Australian Economic Studies.

Dwyer, L., P. Forsyth, and R. Spurr. 2005. "Estimating the Impacts of Special Events on an Economy." Journal of Travel Research 43 (4): 351.

Elias-Varotsis, S. 2006. "Festivals and Events: (re)interpreting cultural identity." Tourism Review 61 (2): 24-29. 
Essex, S., and B. Chalkley. 1998. "Olympic Games: Catalyst of Urban Change." Leisure Studies 17 (3): 187.

Essex, S., and B. Chalkley. 2004. "Mega-events as a Strategy for Urban Regeneration.” Dialoghi Internazionali-Città Nel Mondo 5: $18-29$.

European Commission. 2014. European Capitals of Culture 2020 2033. A Guide for Cities Preparing to Bid. European Commission Culture. Accessed September 25, 2015. http://ec.europa.eu/pro grammes/creative-europe/actions/documents/ecoc-candidatesguide_en.pdf.

Falk, M., and E. Hagsten. 2017. "Measuring the Impact of the European Capital of Culture Programme on Overnight Stays: Evidence for the Last Two Decades." European Planning Studies 25 (12): 1-17.

Faulkner, B. 2003. Progressing Tourism Research. Clevedon, UK: Channel View Publications.

Faulkner, H. W. 1993. Evaluating the Tourism Impacts of Hallmark Events. Canberra, Australia: Bureau of Tourism Research.

Fayos-Solá, E. 1998. "The Impact of Mega Events." Annals of Tourism Research 25 (1): 241-45.

Ferm, J., and E. Jones. 2016. “Mixed-use 'Regeneration' of Employment Land in the Post-industrial City: Challenges and Realities in London.” European Planning Studies 24 (10): 1913-36.

Fitch, J. M. 1990. Historic Preservation: Curatorial Management of the Built World. Charlottesville: University of Virginia Press.

Flyvbjerg, B., and A. Stewart. 2012. "Olympic Proportions: Cost and Cost Overrun at the Olympics 1960-2012." Saïd Business School Working Papers, Saïd Business School, Oxford, 1-23.

Foley, M., D. McGillivray, and G. McPherson. 2012. Event Policy: From Theory to Strategy. London, UK: Routledge.

Fourie, J., and M. Santana-Gallego. 2011. "The Impact of Mega-sport Events on Tourist Arrivals." Tourism Management 32 (6): 1364.

Gabrielli, B. 2005. "Genova, un piano strategico di natura operativa ei suoi esiti." Urbanistica 126: 57.

Gale, D. 1991. "The Impacts of Historic District Designation Planning and Policy Implications." Journal of the American Planning Association 57 (3): 325.

Gammon, S., G. Ramshaw, and E. Waterton. 2013. "Examining the Olympics: Heritage, Identity and Performance." International Journal of Heritage Studies 19 (2): 119-124.

García, B. 2005. "Deconstructing the City of Culture: The Long-term Cultural Legacies of Glasgow 1990." Urban Studies 42 (5): 841-68. doi:10.1080/00420980500107532.

García, Beatriz, and T. Cox. 2013a. European Capitals of Culture: Success Strategies and Long-term Effects. Luxembourg: European Parliament Committee on Culture and Education.

García, Beatriz, and T. Cox. 2013b. London 2012 Cultural Olympiad Evaluation. Liverpool, UK: Institute of Cultural Capital.

García, Beatiz, R Melville, and T. Cox. 2010. Creating an Impact: Liverpool's Experience as European Capital of Culture. Institute of Cultural Capital. Liverpool, UK: Impacts 08.

Garden, M.-C. E. 2006. "The Heritagescape: Looking at Landscapes of the Past.” International Journal of Heritage Studies 12 (5): 394.

Gastaldi, F. 2016. “Genoa, a Success Story!” In Waterfronts Revisited: European Ports in a Historic and Global Perspective, edited by $\mathrm{H}$. Porfyriou and M. Sepe, 123. New York: Routledge.
Getz, D. 2008. "Event Tourism: Definition, Evolution, and Research." Tourism Management 29 (3): 403.

Getz, D., and S. J. Page. 2016. "Progress and Prospects for Event Tourism Research.” Tourism Management 52: 593.

Getzner, M., and C. Oberlercher. 2003. "Small Museums and the Regional Economy: An Austrian Case Study." Wirtschaftspolitische Blatter 50 (2): 271.

Glendinning, M. 2013. The Conservation Movement: A History of Architectural Preservation: Antiquity to Modernity. London, UK: Routledge.

Gold, J. R., and M. M. Gold. 2008. "Olympic Cities: Regeneration, City Rebranding and Changing Urban Agendas." Geography Compass 2 (1): 300 .

Goldman, M. 2011. "Speculative Urbanism and the Making of the Next World City." International Journal of Urban and Regional Research 35 (3): 555-81.

Grabar, H. 2014. "Save Our Cities from Tourists! For the World's Greatest Cities, Tourism Has Become Both a Blessing and a Curse." Salon. Accessed November 26, 2015. http://www.salon. com/2014/04/27/save_our_cities_from_tourists/.

Grabher, G., and J. Thiel. 2015. "Projects, People, Professions: Trajectories of Learning through a Mega-event (the London 2012 Case)." Geoforum 65: 328-37.

Greenhalgh, P. 2011. Fair World: A History of World's Fairs and Expositions, from London to Shanghai, 1851-2010. Winterbourne, Berks, UK: Papadakis.

Hall, C. M. 1989. "The Definition and Analysis of Hallmark Tourist Events." Geo Journal 19 (3): 263.

Hall, C. M. 1992. Hallmark Tourist Events: Impacts, Management and Planning. London, UK: Belhaven Press.

Hall, C. M. 2006. "Urban Entrepreneurship, Corporate Interests and Sports Mega-events: The thin Policies of Competitiveness within the Hard Outcomes of Neoliberalism." The Sociological Review 54 (s2): 59 .

Harrison, R. 2013. Heritage: Critical Approaches. London, UK: Routledge.

Harvey, D. C. 2008. "The History of Heritage." In The Ashgate Research Companion to Heritage and Identity, edited by B. Graham and P. Howard, 19. Hampshire, UK: Ashgate.

Haxton, A. 2003. "Community Involvement and the Olympic Games: A Review of Related Research." Presented at the 7th International Postgraduate Seminar on Olympic Studies, Athens, Greece: IOA.

Healy, R. G. 1992. "The Role of Tourism in Sustainable Development." Paper presented at 4th World Congress on National Parks and Protected Areas. Caracas, Venezuela, February, 10.

Herrero, L. C., J. Sanz, M. Devesa, A. Bedate, and M. J. Del Barrio. 2006. "The Economic Impact of Cultural Events: A Case-study of Salamanca 2002, European Capital of Culture.” European Urban and Regional Studies 13 (1): 41-57.

Hiller, H. H. 2000. "Mega-events, Urban Boosterism and Growth Strategies: An Analysis of the Objectives and Legitimations of the Cape Town 2004 Olympic Bid." International Journal of Urban and Regional Research 24 (2): 449.

Hiller, H. H. 2006. "Post-event Outcomes and the Post-modern Turn: The Olympics and Urban Transformations.” European Sport Management Quarterly 6 (4): 317. 
Horne, J. 2007. “The Four 'Knowns' of Sports Mega-events.” Leisure Studies 26 (1): 81-96.

Horne, J., and G. Whannel. 2016. Understanding the Olympics. London, UK: Routledge.

Hughes, H. L. 1993. "Olympic Tourism and Urban Regeneration." Festival Management and Event Tourism 1 (4): 157.

ICOMOS (International Council on Monuments and Sites). 1964. "International Charter for the Conservation and Restoration of Monuments and Sites." Second International Congress of Architects and Technicians of Historic Monuments, Venice.

ICOMOS (International Council on Monuments and Sites). 1994. The Nara Document on Authenticity. Paris, France: International Committee on Monuments and Sites.

Ijla, A., S. Ryberg, M. S. Rosentraub, and W. Bowen. 2011. "Historic Designation and the Rebuilding of Neighborhoods: New Evidence of the Value of an Old Policy Tool." Journal of Urbanism: International Research on Placemaking and Urban Sustainability 4 (3): 263-84.

IOC (International Olympic Committee). 2013. Factsheet. London 2012 Facts \& Figures. International Olympic Committee. Accessed September 25, 2015. http://www.olympic.org/Docu ments/Reference_documents_Factsheets/London_2012_Facts_ and_Figures-eng.pdf.

IOC (International Olympic Committee). 2014. Olympic Agenda 2020: 20+20 Recommendations. Lausanne: International Olympic Committee.

Jacobs, J. 1961. The Death and Life of Great American Cities. New York: Vintage.

Jokilehto, J. 1999. History of Architectural Conservation. New York: Routledge.

Jokilehto, J. 2010. "Reflection on Historic Urban Landscapes as a Tool for Conservation." World Heritage Papers 27: 53.

Jones, Z. 2015. "Mega-Events Decoupled from Long-term Planning: Shortcomings and Learning from the Istanbul 2010 European Capital of Culture." In Book of Proceedings: 29th Annual AESOP 2015 Congress: Definite Space-Fuzzy Responsibility, 2118.

Jones, Z. M. 2017. "Synergies and Frictions between Mega-events and Local Urban Heritage.” Built Heritage 1 (4): 22-36.

Kassens-Noor, E. 2012. Planning Olympic Legacies: Transport Dreams and Urban Realities. London, UK: Routledge.

Kassens-Noor, E. 2013. "Transport Legacy of the Olympic Games, 1992-2012.” Journal of Urban Affairs 35 (4): 393.

Kim, W., H. M. Jun, M. Walker, and D. Drane. 2015. "Evaluating the Perceived Social Impacts of Hosting Large-scale Sport Tourism Events: Scale Development and Validation." Tourism Management 48: 21.

Kiuri, M., and J. Teller. 2015. "Olympic Stadiums and Cultural Heritage: On the Nature and Status of Heritage Values in Large Sport Facilities." The International Journal of the History of Sport 32 (5): 684.

Koolhaas, R. 2004. "Preservation Is Overtaking Us." Future Anterior 1 (2): 1 .

Kupka, K. 2012. Redevelopment by Tradition: Urban Renewal in World Heritage Cities: The Effects of Plans and Projects in Amsterdam, Florence, Genoa and Venice. Venice, Italy: Libreria Cluva Editrice.
Larkham, P. J. 1996. Conservation and the City. London, UK: Routledge.

Lauermann, J. 2014. "Competition through Interurban Policy Making: Bidding to Host Mega-events as Entrepreneurial Networking." Environment and Planning A 46 (11): 2638-53.

Lee, C.-K., and T. Taylor. 2005. "Critical Reflections on the Economic Impact Assessment of a Mega-event: The Case of 2002 FIFA World Cup.” Tourism Management 26 (4): 595.

Leichenko, R. M., N. E. Coulson, and D. Listokin. 2001. "Historic Preservation and Residential Property Values: An Analysis of Texas Cities." Urban Studies 38 (11): 1973.

Li, X., C. H. Hsu, and L. J. Lawton. 2015. "Understanding Residents' Reservation and Residential Proper-event through a Dual-theory Lens." Journal of Travel Research 54 (3): 396.

Liao, H., and A. Pitts. 2006. "A Brief Historical Review of Olympic Urbanization." The International Journal of the History of Sport 23 (7): 1232 .

Lichfield, N. 1988. Economics in Urban Conservation. Cambridge, UK: Cambridge University Press in Association with Jerusalem Institute for Israel Studies.

Lichfield, N. 1997. "Achieving the Benefits of Conservation." Built Environment 23 (2): 103.

Listokin, D., B. Listokin, and M. Lahr. 1998. "The Contributions of Historic Preservation to Housing and Economic Development." Housing Policy Debate 9 (3): 431-78.

Lowenthal, D. 1998. The Heritage Crusade and the Spoils of History. Cambridge, UK: Cambridge University Press.

Lynch, P., and R. Jensen. 1984. "The Economic Impact of the XII Commonwealth Games on the Brisbane Region." Urban Policy and Research 2 (3): 11.

MacCannell, D. 1976. The Tourist: A New Theory of the Leisure Class. Berkeley: University of California Press.

Magrin, A. 2015. "Italia 1945-1995. Il Progetto Urbanistico Dell Città Storica." In Esportare Il Centro Storico, edited by B. A. Albrecht and A. Magrin, 146-61. Milan, Italy: La Triennale di Milano.

Mairs, J. 2017, September 18. Populous and Egis unveil Masterplan for Paris 2024 Olympic Games. Dezeen. Accessed October 5, 2017. https:/www.dezeen.com/2017/09/18/populous-egis-paris2024-olympic-paralympic-games-park-masterplan-paris-france/.

Malfas, M., B. Houlihan, and E. Theodoraki. 2004. "Impacts of the Olympic Games as Mega-events." Municipal Engineer 157 (ME3): 209-20.

Manrique, C., T. Jamal, and R. Warden. 2016. "Heritage Tourism and Conservation: A Cultural Resilience Bridge?” In Tourism Research Paradigms: Critical and Emergent Knowledges, Tourism Social Science Series, (vol. 22), edited by A. M. Munar and T. Jamal, 17-33. Emerald Group Publishing Limited. https://www.emeraldin sight.com/doi/abs/10.1108/S1571-504320150000022008

Mason, P., and J. Beaumont-Kerridge. 2004. "Motivations for Attendance at the 2001 Sidmouth International Festival: Fun, Family, Friends, Fulfilment or Folk." Festivals and Tourism: Marketing, Management and Evaluation 33: 33-46.

Mason, R. 2004. "Fixing Historic Preservation: A Constructive Critique of" Significance" [Research and Debate]." Places 16 (1): 64-71. 
Mason, R. 2005. Economics and Historic Preservation: A Guide and Review of the Literature. Washington, DC: The Brookings Institution, 35-100.

Mason, R. 2008. "Be Interested and Beware: Joining Economic Valuation and Heritage Conservation." International Journal of Heritage Studies 14 (4): 303.

Mason, R., and E. Avrami. 2002. "Heritage Values and Challenges of Conservation Planning." In Management Planning for Archaeological Sites: An International Workshop Organized by the Getty Conservation Institute and Loyola Marymount University, edited by J. M. Teutonico and G. Palumbo, 13-26. Los Angeles, CA: The Getty Conservation Institute.

Mason, R., and M. De la Torre. 1999. Economics and Heritage Conservation. Los Angeles, CA: Getty Conservation Institute.

Mason, R., and M. De la Torre. 2000. "Heritage Conservation and Values in Globalizing Societies." World Culture Report 2000: Cultural Diversity, Conflict and Pluralism, 164-179. Paris, France: UNESCO.

Matero, F. 2011. "Being Modern: The Currency of Conservation." In Architectural Conservation in Europe and the Americas, edited byStubbs, J. H., and E. G. Makas, xvi-xx. Hoboken, NJ: John Wiley.

Matheson, V. 2006. "Mega-events: The Effect of the World's Biggest Sporting Events on Local, Regional, and National Economies". Economics Department Working Papers, Paper 68. Accessed August 15, 2016. http://crossworks.holycross.edu/econ_working_ papers/68.

McGillivray, D., and G. McPherson. 2012. "Mega Events: Neoliberalized Vehicle or Opportunity for Strategic Global Leadership." Journal of Leadership, Accountability and Ethics 9 (5): 80.

Meskell, L. 2012. "The Rush to Inscribe: Reflections on the 35th Session of the World Heritage Committee, UNESCO Paris, 2011." Journal of Field Archaeology 37 (2): 145-51.

Meskell, L. 2013. "UNESCO's World Heritage Convention at 40: Challenging the Economic and Political Order of International Heritage Conservation.” Current Anthropology 54 (4): 483-94.

Mooney, G. 2004. "Cultural Policy as Urban Transformation? Critical Reflections on Glasgow, European City of Culture 1990." Local Economy 19 (4): 327.

Morandi, C., and S. Di Vita. 2017. Mega-events and Legacies in Postmetropolitan Spaces: Expos and Urban Agendas. Palgrave Macmillan.

Mules, T. 1993. "A Special Event as Part of an Urban Renewal Strategy." Festival Management and Event Tourism 1 (2): 651.

Mules, T., and B. Faulkner. 1996. "An Economic Perspective on Special Events." Tourism Economics 2 (2): 107.

Müller, Martin. 2014. "The Topological Multiplicities of Power: The Limits of Governing the Olympics." Economic Geography 90 (3): 321-39.

Müller, Martin. 2015. "The Mega-event Syndrome: Why So Much Goes Wrong in Mega-event Planning and What to Do about It." Journal of the American Planning Association 81 (1): 6-17.

Müller, Martin, and J. Pickles. 2015. "Global Games, Local Rules: Mega-events in the Post-socialist World." European Urban and Regional Studies 22 (2): 121-27.
Naidoo, R., and J. Littler. eds. 2005. The Politics of Heritage: The Legacies of Race. New York: Routledge.

Nasser, N. 2003. "Planning for Urban Heritage Places: Reconciling Conservation, Tourism, and Sustainable Development." Journal of Planning Literature 17 (4): 467.

Neagu, M., M. Ripp, N. Scheffler, and P. Stein. 2017. Community-led Urban Strategies in Historic Towns (COMUS): Communities at the Heart of Heritage. Principles for Heritage Based Urban Development of Small and Medium-sized Heritage Towns in Countries in Transition. Strasbourg, France: Council of Europe.

Nuryanti, W. 1996. "Heritage and Postmodern Tourism." Annals of Tourism Research 23 (2): 249-60.

O'Brien, D. 2011. "Who Is In Charge? Liverpool, European Capital of Culture 2008 and the Governance of Cultural Planning." Town Planning Review 82 (1): 45-59. doi:10.3828/tpr.2011.2.

Olwig, K. R. 2005. "Introduction: The Nature of Cultural Heritage, and the Culture of Natural Heritage-Northern Perspectives on a Contested Patrimony." International Journal of Heritage Studies 11 (1): 3-7.

Page, M., and R. Mason. eds. 2004. Giving Preservation a History: Histories of Historic Preservation in the United States. New York: Psychology Press.

Palmer/RAE Associates. 2004. European Cities and Capitals of Culture. Part I. Brussels, Belgium: European Commission.

Papanikolaou, P. 2012. "The European Capital of Culture: The Challenge for Urban Regeneration and Its Impact on the Cities." International Journal of Humanities and Social Science 2 (17): 268.

Pendlebury, J., T. Townshend, and R. Gilroy. 2004. "The Conservation of English Cultural Built Heritage: A Force for Social Inclusion?" International Journal of Heritage Studies 10 (1): 11.

Pereira, H. N. 2007. "Contemporary Trends in Conservation: Culturalization, Significance and Sustainability." City \& Time 3 (2): 2.

Pereira Roders, A., and R. van Oers. 2011. "World Heritage Cities Management." Facilities 29 (7/8): 276.

Pinson, J. 2016. "Heritage Sporting Events in Territorial Development." In Heritage Tourism Destinations: Preservation, Communication and Development, edited by M. Alvarez, F. Go, and A. Yuksel, 76-90. Boston, MA: CABI.

Plaza, B. 2006. "The Return on Investment of the Guggenheim Museum Bilbao." International Journal of Urban and Regional Research 30 (2): 452.

Ponzini, D. 2009. "Urban Implications of Cultural Policy Networks: The Case of the Mount Vernon Cultural District in Baltimore." Environment and Planning C: Government and Policy 27 (3): 433-50.

Ponzini, D., and Z. Jones. 2015. "Meanings, Urban Products and Forms of 'European Cities' in the European Capital of Culture Program." Urbanistica 155: 70-78.

Poria, Y., R. Butler, and D. Airey. 2003. "The Core of Heritage Tourism." Annals of Tourism Research 30 (1): 238.

Raco, M. 2014. "Delivering Flagship Projects in an Era of Regulatory Capitalism: State-led Privatization and the London Olympics 2012." International Journal of Urban and Regional Research 38 (1): 176-97. 
Raco, M. 2015. "Sustainable City-building and the New Politics of the Possible: Reflections on the Governance of the London Olympics 2012." Area 47 (2): 124-31.

Raco, M., and E. Tunney. 2010. "Visibilities and Invisibilities in Urban Development: Small Business Communities and the London Olympics 2012." Urban Studies 47 (10): 2069-91.

Rees, M. 2000. Issues in Evaluation: Events beyond 2000: Setting the Agenda. Sydney: Australian Centre for Event Management, 75.

Regan, N., J. Carlson, and P. J. Rosenberger III. 2012. "Factors Affecting Group-oriented Travel Intention to Major Events." Journal of Travel \& Tourism Marketing 29 (2): 185.

Richards, G., and J. Wilson. 2004. "The Impact of Cultural Events on City Image: Rotterdam, Cultural Capital of Europe 2001." Urban Studies 41 (10): 1931. doi:10.1080/0042098042000256323.

Riegl, A. 1903. "The Modern Cult of Monuments: Its Essence and Its Development." In Historical and Philosophical Issues in the Conservation of Cultural Heritage. Edited by N. Stanley-Price, M. Kirby Talley Jr, and A. Mellucco Vaccaro, 69-83. Los Angeles, CA: The Getty Conservation Institute.

Ritchie, J. B., and D. Beliveau. 1974. "Hallmark Events: An Evaluation of a Strategic Response to Seasonality in the Travel Market." Journal of Travel Research 13 (2): 14.

Ritchie, J. B., and B. H. Smith. 1991. "The Impact of a Mega-event on Host Region Awareness: A Longitudinal Study.” Journal of Travel Research 30 (1): 31.

Ritchie, J. B., and J. Yangzhou. 1987. "The Role and Impact of Megaevents and Attractions on National and Regional Tourism: A Conceptual and Methodological Overview." Proceedings of the 37th Congress of AIEST, vol. 28, 17-37.

Rizzo, I., and A. Mignosa. 2013. Handbook on the Economics of Cultural Heritage. Cheltenham, UK: Edward Elgar Publishing.

Rizzo, I., and D. Throsby. 2006. "Cultural Heritage: Economic Analysis and Public Policy." In Handbook of the Economics of Art and Culture, vol. 1, edited by Victor A. Ginsburg and David Throsby, 983-1016. Amsterdam, the Netherlands: Elsevier.

Roche, M. 1992. "Mega-events and Micro-modernization: On the Sociology of the New Urban Tourism." British Journal of Sociology 43(4): 563-600.

Roche, M. 2000. Mega-events and Modernity: The Olympics, Internationalism and Supernationalism: International Sports Events and Movements in the Inter-war Period. New York: Routledge.

Rodwell, D. 2012. "The UNESCO World Heritage Convention, 19722012: Reflections and Directions." The Historic Environment: Policy \& Practice 3 (1): 64-85.

Rodwell, D. 2013. "Heritage as a Driver for Creative Cities." In The Idea of Creative City: The Urban Policy Debate, edited by D. Wiktor-Mach and P. Radwański, 11-26. Cracow, Poland: European Scientific Institute.

Ronström, O. 2014. "Consequenses of World Heritage Production: the Heritage Town.” In Between Dream and Reality: Debating the Impact of World Heritage Listing, edited by H. Hølleland and S. Solheim, 7-17. Primitive Tider special edition. Oslo, Norway: Reprosentralen.

Roy, A., and A. Ong. 2011. Worlding Cities: Asian Experiments and the Art of Being Global, vol. 42. Oxford, UK: John Wiley.
Ruggles, D. F. 2012. "Introduction: The Social and Urban Scale of Heritage." In On Location, edited by D. F. Ruggles, , 1-14. New York: Springer.

Russo, A. P. 2002. "The 'Vicious Cycle' of Tourism Development in Heritage Cities." Annals of Tourism Research 29 (1): 165-182.

Ryberg-Webster, S. 2013. "Preserving Downtown America: Federal Rehabilitation Tax Credits and the Transformation of US Cities." Journal of the American Planning Association 79 (4): 266-79.

Ryberg-Webster, S. 2015. "Urban Policy in Disguise: A History of the Federal Historic Rehabilitation Tax Credit.” Journal of Planning History 14 (3): 204-23.

Ryberg-Webster, S., and K. L. Kinahan. 2014. "Historic Preservation and Urban Revitalization in the Twenty-first Century." Journal of Planning Literature 29 (2): 119.

Rypkema, D. D. 1994. The Economics of Historic Preservation: A Community Leader's Guide. Washington, DC: National Trust for Historic Preservation.

Rypkema, D. D. 2012. "Economics and Historic Preservation." Forum Journal 27 (1): 45-54.

Rypkema, D. D., C. Cheong, and R. Mason. 2013. Measuring Economic Impacts of Historic Preservation: A Report to the Advisory Council on Historic Preservation by Place Economics. Washington, DC: Advisory Council on Historic Preservation.

Schröder-Esch, S. 2006. "Practical Aspects of Cultural Heritage: Presentation, Revaluation, Development." Contributions Presented on the 28th and 29th October 2005 as Part of the 2nd Hermes Symposium in Krakow, Poland. Bauhaus-University.

Scott, A. J. 1997. "The Cultural Economy of Cities." International Journal of Urban and Regional Research 21 (2): 323-39.

Serageldin, I. 1999. Very Special Places: The Architecture and Economics of Intervening in Historic Cities. Washington, DC: World Bank, 23-35.

Settis, S. 2014. Se Venezia muore. Torino, Italy: Einaudi Torino.

Short, J. R. 2008. "Globalization, Cities and the Summer Olympics." City 12 (3): 321.

Short, J. R., and Y.-H. Kim. 1999. Globalization and the City. London, UK: Longman Harlow.

Shoval, N. 2002. "A New Phase in the Competition for the Olympic Gold: the London and New York Bids for the 2012 Games." Journal of Urban Affairs 24 (5): 583.

Silberman, N. 2014. "Changing Visions of Heritage Value: What Role Should the Experts Play?" Ethnologies 36 (1): 433-45.

Soldo, E., C. Arnaud, and O. Keramidas. 2013. "Direct Control of Cultural Events as a Means of Leveraging the Sustainable Attractiveness of the Territory? Analysis of the Managerial Conditions for Success." International Review of Administrative Sciences 79 (4): 725 .

Song, W. 2010. "Impacts of Olympics on Exports and Tourism." Journal of Economic Development 35 (4): 93.

Squire, L., and H. G. Van der Tak. 1975. Economic Analysis of Projects. Baltimore, MD: World Bank.

Stough, R. R. 1994. "Economic Development: Theory and Practice." Historic Preservation Forum 8: 31.

Sykes, O. 2011. "European Cities and Capitals of Culture." Town Planning Review 82 (1). 
Sykes, O., and J. Brown. 2015. "European Capitals of Culture and Urban Regeneration: An Urban Planning Perspective from Liverpool." Urbanistica 155:79.

Throsby, D. 1997. "Seven Questions in the Economics of Cultural Heritage." In Economic Perspectives on Cultural Heritage, edited by Michael Hutter and Ilde Rizzo, 13-30. New York: Springer.

Throsby, D. 2001. Economics and Culture. Cambridge, UK: Cambridge University Press.

Timothy, D. J., and S. W. Boyd. 2003. Heritage Tourism. Harlow, UK: Pearson Education.

Townshend, T., and J. Pendlebury. 1999. "Public Participation in the Conservation of Historic Areas: Case-studies from North-east England." Journal of Urban Design 4 (3): 313-331.

UNESCO (United Nations Educational, Scientific and Cultural Organisation). 1972. Convention Concerning the Protection of the World Cultural and Natural Heritage. Paris, France: UNESCO.

UNESCO (United Nations Educational, Scientific and Cultural Organisation). 2002. Decisions Adopted by the 26th Session of the World Heritage Committee (No. 26 COM). Budapest, Hungary: World Heritage Committee.

UNESCO (United Nations Educational, Scientific and Cultural Organisation). 2007. Proposal for a 'Fifth $C$ ' to be Added to the Strategic Objectives (No. 31 COM). Christchurch, New Zealand: World Heritage Committee.

UNESCO (United Nations Educational, Scientific and Cultural Organisation). 2016. Global Report on Culture for Sustainable Urban Development. Paris, France: UNESCO.

UNWTO. 2011. Tourism towards 2030: Global Overview. Accessed September 30, 2016. http://media.unwto.org/sites/all/files/pdf/ unwto_2030_ga_2011_korea.pdf.

Van der Borg, J., and A. P. Russo. 1999. "Tourism Management in Heritage Cities." Proceedings of the First International Seminar, Venice, Italy: UNESCO, Venice Office.

Vanolo, A. 2015. "The Image of the Creative City, Eight Years Later: Turin, Urban Branding and the Economic Crisis Taboo." Cities 46: $1-7$.
Veldpaus, L., A. R. Pereira Roders, and B. J. F. Colenbrander. 2013. "Urban Heritage: Putting the Past into the Future." The Historic Environment: Policy \& Practice 4 (1): 3.

Waitt, G. 2003. "Social Impacts of the Sydney Olympics." Annals of Tourism Research 30 (1): 194.

Watt, P. 2013. "'It's not for us'. Regeneration, the 2012 Olympics and the Gentrification of East London." City 17 (1): 99-118.

Willems, W. J. H. 2014. "The Future of World Heritage and the Emergence of Transnational Heritage Regimes." Heritage \& Society 7 (2): 105.

Wojno, C. T. 1991. "Historic Preservation and Economic Development." Journal of Planning Literature 5 (3): 296.

Wolf, B., D. Horn, and C. Ramirez. 1999. Financing Historic Federal Buildings: An Analysis of Current Practice. Washington, DC: General Services Administration, Public Buildings Service, Office of Business Performance.

Zhang, Y. 2008. "Steering towards Growth: Symbolic Urban Preservation in Beijing, 1990-2005." Town Planning Review 79 (2-3): 187-208.

Zukin, S. 1995. The Cultures of Cities, vol. 150. Oxford: Blackwell.

Zukin, S. 2009. Naked City: The Death and Life of Authentic Urban Places. Oxford, UK: Oxford University Press.

\section{Author Biographies}

Zachary M. Jones is a current Research Fellow at the Politecnico di Milano where he completed his PhD in Urban Planning, Design and Planning. His research interests span architectural and urban design, planning, built heritage, large scale events and cultural policy.

Davide Ponzini is an Associate Professor of Urban Planning at the Politecnico di Milano. His research activity focuses on planning theory, urban and cultural policy, and contemporary architecture. He has authored several books and journal articles on these topics. 